\title{
Default soberanos: la necesidad de reforma a la arquitectura financiera internacional a partir de la experiencia de Argentina
}

Flavio Ernesto Buchieri

Prof. Adjunto. Facultad de Ciencias Económicas -

Universidad Nacional de Villa María

Email: flavio.buchieri@gmail.com

Fecha de recepción

$13 / 10 / 2014$

Fecha de aprobación $12 / 11 / 2014$

Palabras clave

- holdouts

- valor nominal

- valor presente

- canje de deuda

Keywords

- holdouts

- nominal value

- present value

- debt exchange

\section{Resumen}

Argentina está en su segundo default en menos de quince años, debido a causas propias como al diseño jurídico internacional que contiene la emisión de deuda soberana en la actualidad. En este escenario es una prioridad generar mecanismos que eviten el comportamiento oportunístico de acreedores que no ingresaron a procesos de re-estructuración de tales deudas como lo revela el caso Argentino. De este rediseño en el manejo de deudas soberanas depende el éxito de futuros procesos de rescate de bonos nacionales.

\footnotetext{
Abstract

Argentina is in its second default in least tan fifteen years, due own reasons as well as the international framework which contain the emission of sovereign debt in the present. In this scenario, it's a priority to generate mechanisms that avoid the opportunistic behavior of creditors that didn't enter to restructuration debt process as the argentine case reveals. From this redesign in the management of sovereign debts depends the success of future recue process of national bonds.
} 